\title{
Experiment and Modeling to Evaluate the Effect of Total Solid on Biogas Production from the Anaerobic Co-Digestion of Tofu Liquid Waste and Rice Straw
}

\author{
Budiyono Budiyono1, Iqbal Syaichurrozi ${ }^{2 *}$, Suhirman Suhirman², \\ Topik Hidayat ${ }^{2}$, Jayanudin Jayanudin² \\ ${ }^{1}$ Department of Chemical Engineering, Faculty of Engineering, University of Diponegoro, Semarang 50239, Indonesia \\ ${ }^{2}$ Department of Chemical Engineering, Faculty of Engineering, University of Sultan Ageng Tirtayasa, \\ Jl. Jendral Soedirman Km 3, Cilegon 42435, Indonesia
}

Received: 15 June 2020

Accepted: 5 September 2020

\begin{abstract}
Anaerobic co-digestion of tofu liquid waste and rice straw is an impressive study as the mixture of both wastes produced substrates with ideal total solid content. This study aims to analyze the effect of rice straw addition $(0,1,3,5$ and $7 \mathrm{~g})$ to $250 \mathrm{~mL}$ tofu liquid waste on biogas yield. The rice straw addition resulted different variations of total solid which were 1.36, 1.67, 2.28, 2.89 and 3.49\% w/w respectively. The increase in total solid content from 1.36 to $2.89 \% \mathrm{w} / \mathrm{w}$, proportionally increased biogas yield from 58.66 to $130.44 \mathrm{~mL} / \mathrm{g}$ TS. However, with total solid of $3.49 \% \mathrm{w} / \mathrm{w}$, biogas yield would be decreased to $78.38 \mathrm{~mL} / \mathrm{g}$ TS. Furthermore, the more the biogas yield was obtained, the more the total solid was removed. Biogas evolution profile followed the stepped curve and it was successfully modeled through double modified Gompertz models. The predicted optimum TS level to produce the highest amount of biogas yield (239.63 mL/g TS), after mixing with the total solid value of $3.14 \% \mathrm{w} / \mathrm{w}$ was successfully calculated through the Ratkowsky model.
\end{abstract}

Keywords: biogas, co-digestion, rice straw, tofu liquid waste, total solid

\section{Introduction}

Anaerobic digestion (AD) is one of treatment methods, that is widely applied in treating many organic wastes successfully [1-2]. It is superior to others, as

*e-mail: iqbal_syaichurrozi@untirta.ac.id iqbalsyaichurrozi@gmail.com it is cost effective [3]. Furthermore, the method can treat high pollutant content [4] and yields biogas as alternative energy [5], which is produced following the degradation of organic compounds during anaerobic digestion [6-9]. Therefore, the organic compound concentration is an important factor affecting biogas generation.

Generally, the organic concentration is presented by the total solid content (TS). Too high or too low TS 
level could hamper the bacterial activity [4]. To adjust the TS content, commonly, water is added. Optimum TS for AD of cattle manure, agricultural wastes, water hyacinth, cow dung, municipal solid waste, banana stem waste and Jatropha curcas seed cake was 7.4-9.2\% [10], 9\% [11], 7-9\% [12], 7.66\% [13], 10\% [14], $2-4 \%$ [15] and 4.8\%, respectively [16]. The optimum TS content is different for each kind of biogas feedstock. Besides water addition, adjustment of TS could be conducted by co-digestion concept. In this way, two wastes with different characteristics are mixed to be one.

This work studied the anaerobic co-digestion of tofu liquid waste (TLW) and rice straw (RS). To produce $80 \mathrm{~kg}$ tofu, industries generate approximately 70 and $2610 \mathrm{~kg}$ for solid and liquid wastes respectively [17]. The former can serve as cattle animal fodder but the latter is directly disposed to the water bodies. Meanwhile, the rice straw is a huge amount of solid waste usually produced by agricultural sector in Indonesia [18]. The TLW contains too low TS level and the RS contains too high TS level. Therefore, co-digestion of the two wastes needs to be performed in order to ascertain the optimum TS for the mixture substrate.

Modeling is an important part of AD. Biogas evolution can be modeled using the modified Gompertz model. Some kinetic parameters in the model can help to explain the phenomena of AD quantitatively [4]. This model was suitable to fit the biogas evolution profile with sigmoid shape, which was the common shape of biogas evolution, so this work used the model. Furthermore, the optimum TS for the co-digestion was predicted through the Ratkowsky model. Previous authors used this model to figure the effect of $\mathrm{pH}$ and temperature on biogas yield [19]. Furthermore, it was tried to describe the effect of Carbon Oxygen Demand per Nitrogen $(\mathrm{COD} / \mathrm{N})$ ratio on biogas yield [5]. Moreover, this work utilized this model to describe the effect of TS level on biogas yield and then to find the optimum TS value.

Based on the information above, this work was new because experimental study and modeling of the codigestion of TLW and RS has not been conducted by other authors yet. The goals of this work included (1) to study the biogas production from the co-digestion TLW and RS, (2) to model the biogas evolution using modified Gompertz model, (3) to predict of optimum TS using Ratkowsky model.

\section{Experimental}

\section{Materials}

The TLW was obtained from a local tofu industry located in Serang city (Banten-Indonesia). It contained TS of $1.36 \% \mathrm{w} / \mathrm{w}$ and had power of Hydrogen $(\mathrm{pH})$ of 3.4 . Meanwhile, the RS was obtained from local rice fields in Bayah Regency (Banten-Indonesia) and It had TS of $94.48 \% \mathrm{w} / \mathrm{w}$. The inoculum (rumen fluid) was obtained from rumen fluid collected from a slaughterhouse in Serang city (Banten-Indonesia).

\section{Experimental Setup}

Some the polyethylene bottles of $600 \mathrm{~mL}$ were modified to be used as lab scale digester for producing biogas. To get anaerobic condition, the bottles were plugged using rubbers. This experimental set up was also used by previous studies $[9,18]$.

\section{Experimental Design and Procedures}

Tofu liquid waste as much as $250 \mathrm{~mL}$ was mixed with rice straw of different masses $(0,1,3,5,7 \mathrm{~g})$ in empty digesters. Thereafter, AD was performed under room temperature with initial $\mathrm{pH}$ of 7. Adjustment of initial $\mathrm{pH}$ was done by addition of $1 \mathrm{M} \mathrm{NaOH}$. Daily biogas volume value was determined through water displacement method [18, 20-22]. Meanwhile, the biogas yield $(\mathrm{mL} / \mathrm{g}$ TS) was determined by dividing the biogas volume $(\mathrm{mL})$ by initial total solid of substrates (g TS) (adapted from Syaichurrozi et al., [20]). Meanwhile, change in $\mathrm{pH}$ during $\mathrm{AD}$ process was recorded using a digital $\mathrm{pH}$ meter. Initial and final TS were determined using standard method of APHA and the TS removal was estimated by Eq. (1) [20]. The variables of this study were shown in Table 1 .

$$
\text { TS Removal }(\%)=\frac{\text { initial TS }(\mathrm{g})-\text { final TS }(\mathrm{g})}{\text { initial TS }(\mathrm{g})} \times 100 \%
$$

Table 1. Result of anaerobic co-digestion digestion of tofu liquid waste and rice straw.

\begin{tabular}{|c|c|c|c|c|c|c|}
\hline Digester code & $\begin{array}{c}\text { Tofu liquid waste } \\
(\mathrm{mL})\end{array}$ & Rice straw $(\mathrm{g})$ & $\begin{array}{c}\text { Total solid } \\
(\% \mathrm{w} / \mathrm{w})\end{array}$ & Initial $\mathrm{pH}$ & $\begin{array}{c}\text { Biogas yield } \\
(\mathrm{mL} / \mathrm{g} \text { TS })\end{array}$ & $\begin{array}{c}\text { TS removal } \\
(\%)\end{array}$ \\
\hline A & 250 & 0 & 1.36 & 7 & 58.66 & 13.26 \\
\hline B & 250 & 1 & 1.67 & 7 & 79.66 & 97.14 \\
\hline C & 250 & 3 & 2.28 & 7 & 123.76 & 97.68 \\
\hline D & 250 & 5 & 2.89 & 7 & 130.44 & 97.38 \\
\hline E & 250 & 7 & 3.49 & 7 & 78.38 & 98.41 \\
\hline
\end{tabular}




\section{Modeling}

Biogas evolution profile was predicted using the modified Gompertz model. This model was suitable to simulate sigmoid biogas profile. By the model, the maximum biogas yield could be estimated. Formula of the model was shown in Eq. (2) [4, 23-24]. In the model, the adjustable kinetic parameters were $\mathrm{ym}, \lambda, \mu$.

$$
y(t)=y m \cdot \exp \left\{-\exp \left[\frac{\mu \cdot e}{y m}(\lambda-t)+1\right]\right\}
$$

...where: ym, maximum biogas yield (mL/g TS); y(t), biogas yield at $\mathrm{t}$ day $(\mathrm{mL} / \mathrm{g}$ TS); $\lambda$, lag time (days); $\mu$, biogas production rate $(\mathrm{mL} / \mathrm{g}$ TS.day); t, digesting time (days); e, mathematical constant (2.72).

Furthermore, the correlation between TS level and maximum biogas yield obtained from modified Gompertz model was predicted through Ratkowsky model. By the model, the optimum TS level could be estimated. The equation of the model was shown in Eq. (3) (adapted from [5]).

$y m=\left[A\left(T S-T S_{\min }\right)\right]^{2}\left\{1-\exp \left[B\left(T S-T S_{\max }\right)\right]\right\}^{2}$

...where: A, B, Ratkowsky parameters

The models were solved using Microsoft Excel to find the adjustable kinetic parameters with subjective function of Sum of Square Error (SSE) (Eq. 4)).

$$
S S E=\sum_{i}^{n}\left(\text { Measured data } a_{i}-\text { Predicted data }_{i}\right)^{2}
$$

\section{Results and Discussion}

\section{Biogas Production}

Table 1 showed the result of AD in treating mixture substrates of tofu liquid waste and rice straw, while evolution of biogas production was shown in Fig. 1. AD of TLW only (digester A) just resulted in biogas of $58.66 \mathrm{~mL} / \mathrm{g}$ TS. In addition, the biogas from digester A was resulted just until day 16 . It was caused by very low TS content in digester A (Table 1).

Meanwhile, digester B-E resulted in more biogas yield than digester $\mathrm{A}$ due to the addition of RS and the TS content in these digesters was $1.67-3.49 \% \mathrm{w} / \mathrm{w}$. The most biogas yield was obtained from digester $\mathrm{D}$ having TS of $2.89 \% \mathrm{w} / \mathrm{w}$ (Table 1). A previous study reported that $\mathrm{AD}$ of vinasse resulted maximum biogas yield when it contained TS of 7-9\% w/w [4]. Vinasse is a liquid waste with more simple organic matters (such as glucose, acetic acid and ethanol) than complex organic matters (such as sucrose) [25-26]. Opposite results were shown by this work. The good TS level in AD of mixture substrates of TLW and RS was $2.89 \%$ w/w with biogas yield of $130.44 \mathrm{~mL} / \mathrm{g}$ TS. RS contains high lignocellulosic compounds are not easily degraded. According to Panico et al. [27], chemical compounds in substrates affect the hydrolysis rate. Therefore, large amounts of water was needed to degrade it in the hydrolysis phase. Hence, the lower TS level was needed in this work compared with a previous study [4]. Substrates containing high readily biodegradable compounds are easily disintegrated in water than substrate having high slowly biodegradable compounds (such as lignocellulosic compounds). Furthermore, the TS of $3.49 \% \mathrm{w} / \mathrm{w}$ was too high TS level so that it resulted lower biogas yield than TS of $2.89 \% \mathrm{w} / \mathrm{w}$. Addition of $7 \mathrm{~g}$ RS (TS of $3.49 \% \mathrm{w} / \mathrm{w}$ ) increased the lignin content in the substrates. Meanwhile, one of products from degradation of lignin is phenol, which can disturb the AD process $[5,28]$.

The profile of biogas evolution during process was shown in Fig. 1. The shape of biogas evolution followed a stepped curve [29]. which has sigmoid curves which were sigmoid 1 (exponential 1, plateau 1) and sigmoid 2 (exponential 2 and plateau 2). In exponential 1, biogas was generated from degradation of simple carbohydrates (non-fiber carbohydrates). All of variables had the same period of exponential 1 which was day $0-4$. After that (above day 4), biogas production rate decreased. In this phase, called as plateau 1, low production rate was due to the low availability of simple carbohydrates because most of them had been degraded in the previous phase. The period of plateau 1 for all variables was approximately day 4-16.

Furthermore, biogas production rate increased again because the fiber carbohydrates were started to be generated. This phase was called as exponential 2 . RS was a lignocellulosic material having high fiber carbohydrates. The fiber carbohydrates were more difficult to be degraded than the non-fiber ones. Digester A (TLW only) did have this phase since biogas was stop. In other words, it just had exponential 1 and plateau 1 phases. The phase of exponential 2 for digester B-E was approximately day 16-42 or 48. Moreover, biogas production decreased again and this phase was called as plateau 2. This phase showed that the availability of fiber carbohydrates was low. This phase occurred from day 42 or 48 until end of AD for digester B-E.

The change in $\mathrm{pH}$ was also monitored and shown in Fig. 1. The fluctuation of $\mathrm{pH}$ was caused by production of volatile fatty acids (VFAs) and total ammonia nitrogen (TAN). However, the range of $\mathrm{pH}$ was still good for $\mathrm{AD}$ process because it was commonly above 5. Commonly, $\mathrm{pH}$ decreased until particular day, after that it increased until end of digestion time. Decrease in $\mathrm{pH}$ was caused by accumulation VFAs produced by degradation of carbon source. In first digestion time, $\mathrm{pH}$ decreased more sharply in Digester A (TLW only) than the others. It showed that VFAs in Digester A is in larger amount than it in other digesters. The VFAs is intermediate products in biogas formation. The more the VFAs is in system, the more the biogas will be resulted. Hence, in sigmoid 1 (including 
exponential 1 and plateau 1) biogas yield from Digester A was more than the others. In other side, $\mathrm{pH}$ decreased slower in Digester B-E. Presence of RS forced bacteria to adapt so organic matter was consumed to it and to produce VFAs. As a consequence, the VFAs amount was low and biogas yield was low in sigmoid 1 . Furthermore, the increase in $\mathrm{pH}$ was caused by TAN accumulation which was generated from degradation of nitrogen source in substrates.
Table 1 shows the TS removal for all variables. Furthermore, correlation between TS level on biogas yield and TS removal is shown in Fig. 2. Good correlation was successfully obtained in which the higher the biogas yield, the higher the TS removal. It was reasonable because biogas was generated from degradation of organic materials.
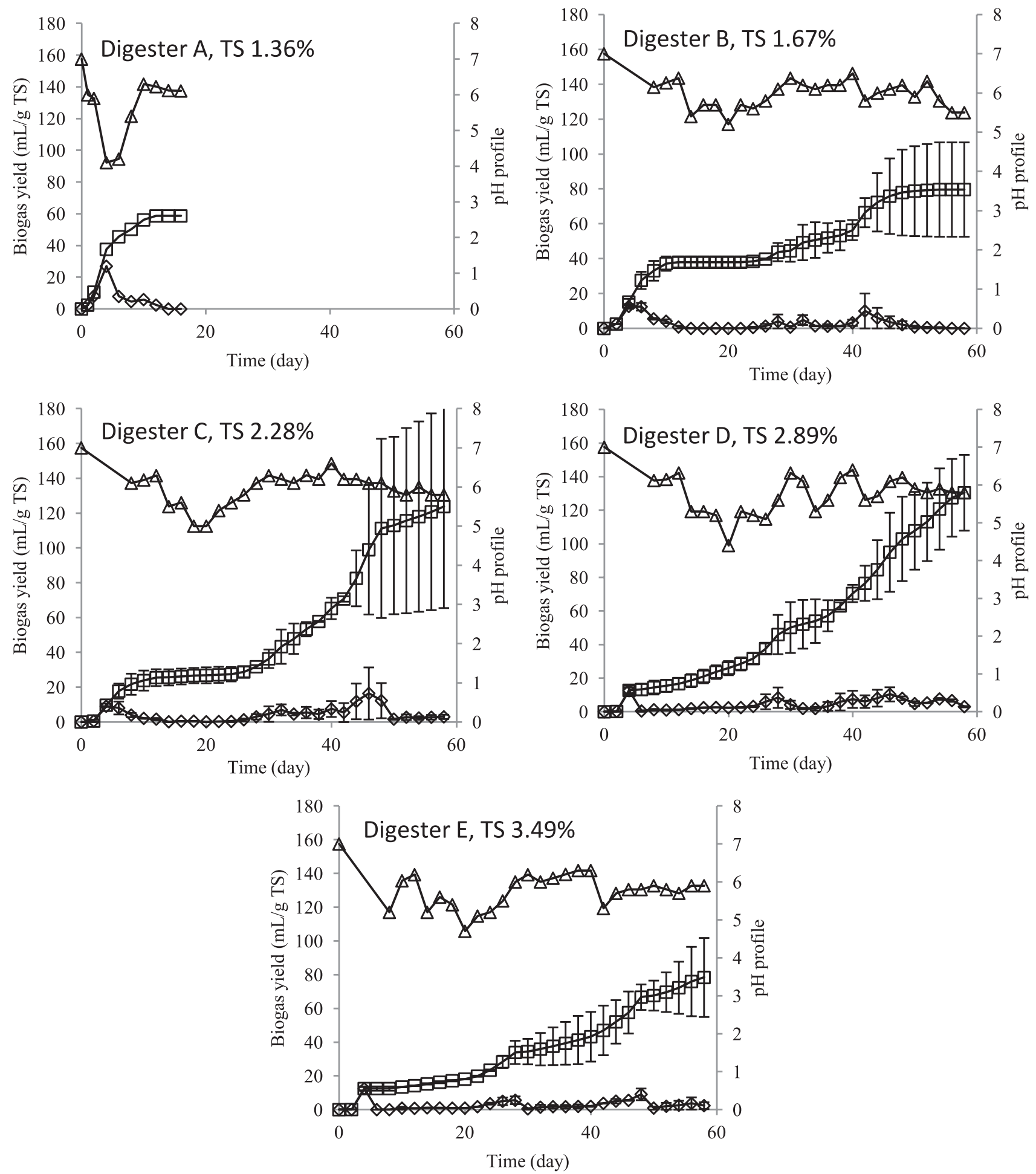

Fig. 1. The effect of total solid concentration on biogas production daily $(\diamond)$, biogas production cumulative $(\square)$, $\mathrm{pH}$ profile $(\Delta)$. 


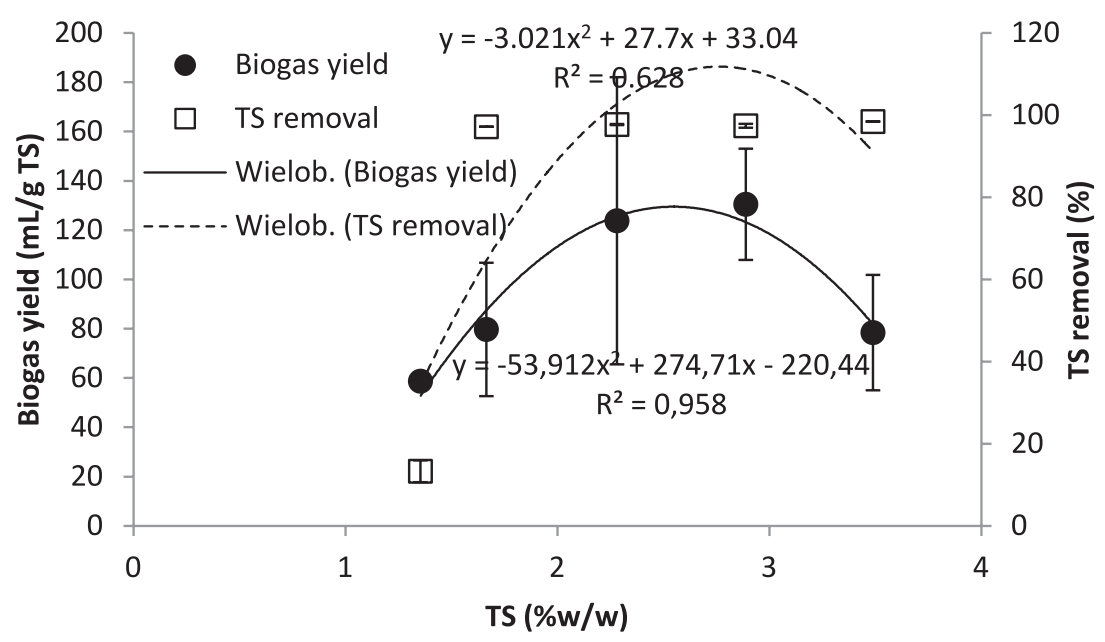

Fig. 2. Correlation between TS level on biogas yield and TS removal.
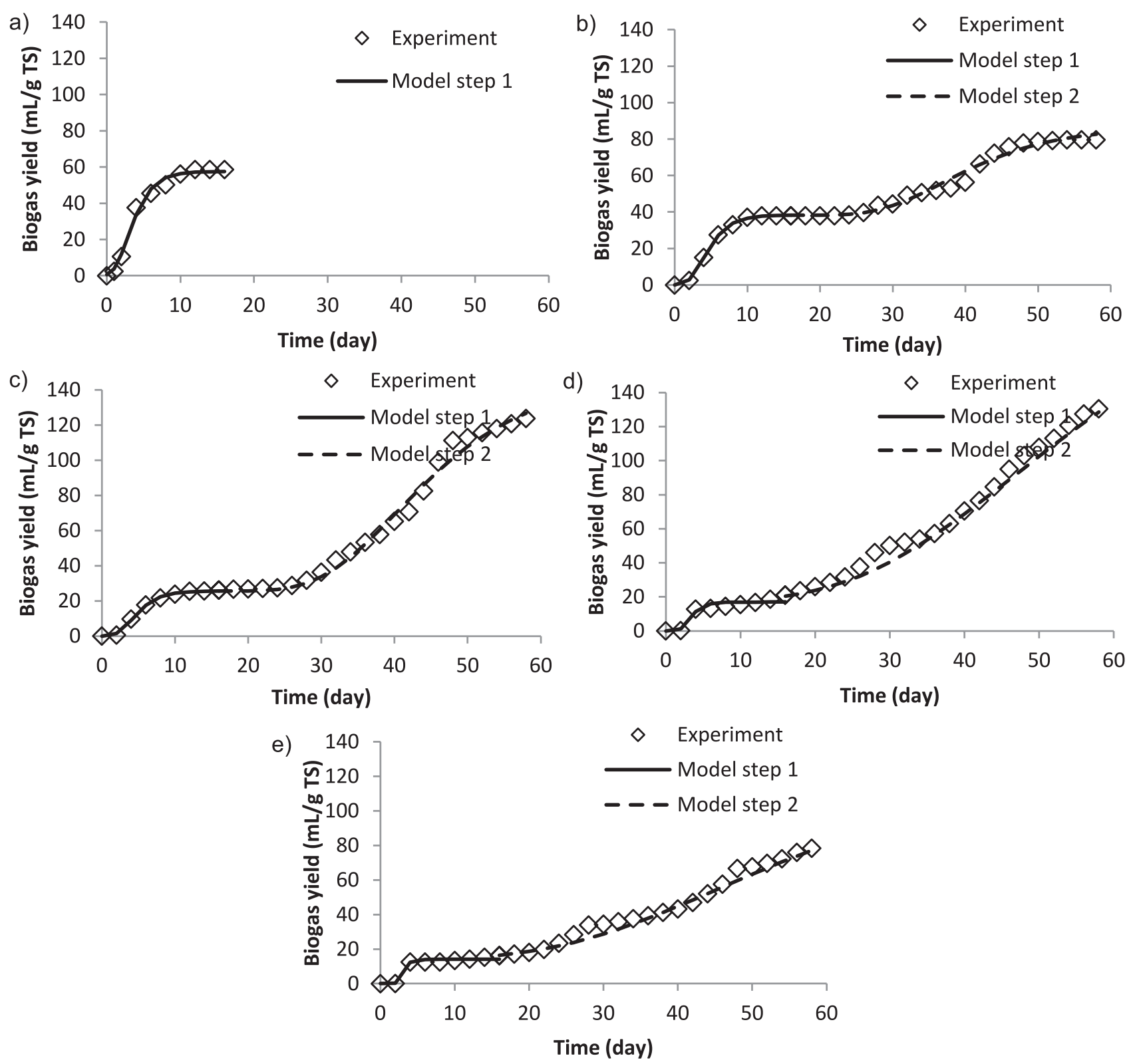

Fig. 3. Plot model step 1 and step 2 in digester (A) TS 1.36\% w/w, (B) TS 1.67\% w/w, (C) TS 2.28\% w/w, (D) TS 2.89\% w/w, (E) TS $3.49 \% \mathrm{w} / \mathrm{w}$. 
Table 2. Results of modeling using modified Gompertz model.

\begin{tabular}{|c|c|c|c|c|c|}
\hline \multirow{2}{*}{ Kinetic parameters } & \multicolumn{5}{|c|}{ TS (\%) } \\
\hline & 1.36 & 1.67 & 2.28 & 2.89 & 3.49 \\
\hline \multicolumn{6}{|c|}{ Step 1} \\
\hline ym (mL/g TS) & 57.53 & 38.25 & 25.74 & 16.97 & 14.06 \\
\hline$\lambda$ (days) & 1.01 & 1.93 & 2.07 & 1.94 & 2.26 \\
\hline$\mu$ (mL/g TS.day) & 11.49 & 7.23 & 4.72 & 5.75 & 9.16 \\
\hline SSE & 45.27 & 1.30 & 2.32 & 37.74 & 11.45 \\
\hline \multicolumn{6}{|c|}{ Step 2} \\
\hline ym (mL/g TS) & - & 86.90 & 146.62 & 222.29 & 125.97 \\
\hline$\lambda$ (days) & - & 14.14 & 16.00 & 10.95 & 9.84 \\
\hline$\mu(\mathrm{mL} / \mathrm{g}$ TS.day $)$ & - & 2.05 & 4.32 & 3.42 & 1.86 \\
\hline SSE & - & 128.49 & 294.83 & 236.74 & 171.50 \\
\hline
\end{tabular}

\section{Modified Gompertz Model}

Based on Fig. 1, the shape of biogas evolution profile was stepped curve [29]. It means there were two sigmoid curves. As explanation in section 3.1, step 1 which was sigmoid curve 1 occurred at period of day 0-16 and step 2 (sigmoid curve 2) was in day 16-58. Every sigmoid curve had one exponential and one plateau phase. Therefore, the biogas evolution profile could be not modeled just using one modified Gompertz model. However, there were two modified Gompertz models to model two sigmoid curves respectively. The biogas profile was successfully modeled and depicted in Fig. 3. The kinetic parameters could be seen in Table 2 .

\section{Step 1 (Sigmoid shape 1)}

The addition of RS decreased the kinetic parameter of ym. It defined the maximum biogas yield that could be obtained [30]. It means the presence of RS decreased the maximum biogas yield because RS contained high lignocellulosic compounds. In this step, bacteria degraded organic compounds from TLW to produce biogas easily (digester A, TS $1.36 \% \mathrm{w} / \mathrm{w}$ ). Bacteria just needed short lag time $(\lambda)$ which was 1.01 days. However, by RS addition, the lag time needed by bacteria was longer which was 1.93-2.26 days. Bacteria needed longer lag time when substrates contained more amounts of lignocellulosic compounds. Furthermore, RS addition decreased the biogas production rate $(\mu)$. It showed the biogas production rate per day [31]. Hence, the presence of RS decreased the daily biogas production rate in sigmoid 1.

\section{Step 2 (Sigmoid shape 2)}

In this step, biogas was dominantly resulted from lignocellulosic compounds. As a proof, digester A (TLW only) did not result in biogas again. Bacteria had been able to adapt with lignocellulosic compound. It was proven by the $\lambda$ value where the more the TS level was in substrates, the shorter the lag time would be. This result was in line with Maamri and Amrani [32] in which the increase in TS in biogas feedstock from 12.02 until $35.80 \mathrm{~g} / \mathrm{L}$ decreased the lag time from 4.622 until 1.856 days. Furthermore, biogas production rate $(\mu)$ at digester C and D (TS 2.28-2.89\% w/w) was higher than that in digester $\mathrm{B}$ and $\mathrm{E}$. The digester $\mathrm{E}$ (TS $3.49 \% \mathrm{w} / \mathrm{w}$ ) had lower $\lambda$ value but it had lower biogas production rate. Phenolic compounds might be resulted in high amount in digester $\mathrm{E}$ because degradation of lignocellulosic compounds in hydrolysis step could result those compounds [33-35]. Therefore, bacteria in digester $\mathrm{E}$ could adapt easily in first time but biological activity was disturbed in the middle of process because of phenol generation. They can inhibit bacterial growth through some ways which are reacting with membrane cell and inactivating the essential enzymes and function of genetic materials [4]. The suitable condition for

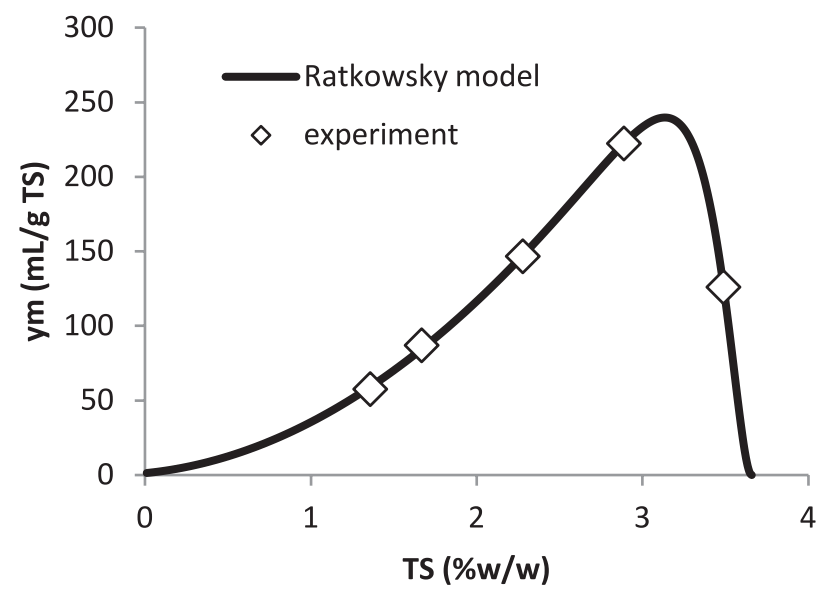

Fig. 4. Correlation between TS level on biogas yield based on Ratkowsky Model. 
Table 3. Results of the Ratkowsky Model.

\begin{tabular}{|c|c|c|}
\hline TS $(\% w / w)$ & $\begin{array}{c}\mathrm{ym} \\
(\mathrm{mL} / \mathrm{g} \mathrm{TS})\end{array}$ & $\begin{array}{c}\mathrm{ym} \\
(\mathrm{mL} / \mathrm{g} \text { TS }) \\
\text { (Ratkowsky model) }\end{array}$ \\
\hline 1.36 & 57.53 & 59.24 \\
\hline 1.67 & 86.90 & 84.54 \\
\hline 2.28 & 146.62 & 147.35 \\
\hline 2.89 & 222.29 & 222.34 \\
\hline 3.49 & 125.97 & 125.88 \\
\hline \multicolumn{3}{|c|}{ Kinetic parameters } \\
\hline $\mathrm{A}$ & 4.83 & \\
\hline B & 5.75 & \\
\hline $\mathrm{TS}_{\min }(\% \mathrm{w} / \mathrm{w})$ & 0.0 & \\
\hline $\mathrm{TS}_{\max }(\% \mathrm{w} / \mathrm{w})$ & 3.66 & \\
\hline Optimum TS $(\% \mathrm{w} / \mathrm{w})$ & 3.14 & \\
\hline SSE & 9.03 & \\
\hline
\end{tabular}

bacteria was in digester $\mathrm{D}$ because it resulted the highest ym and $\mu$ values.

\section{Ratkowsky Model}

By using Ratkowsky model, the correlation between TS level on ym (obtained from section 3.2) was successfully built and shown in Fig. 4. Furthermore, the kinetic parameters of the model were presented in Table 3. Based on Table 3, maximum biogas yield of co-digestion of TLW and RS increased when the TS increased from 0.0 to $3.14 \% \mathrm{w} / \mathrm{w}$. However, it decreased when the TS increased for 3.14 to $3.66 \% \mathrm{w} / \mathrm{w}$. Hence, the optimum TS based on Ratkowsky model was 3.14\% w/w resulting maximum biogas yield of $239.63 \mathrm{~mL} / \mathrm{g}$ TS.

\section{Conclusion}

Biogas yield from anaerobic co-digestion of TLW and RS was successfully conducted. TLW as much as $250 \mathrm{~mL}$ was added RS with different mass $(0,1,3,5$, $7 \mathrm{~g})$. That results in different TS level which was 1.36 , $1.67,2.28,2.89,3.49 \% \mathrm{w} / \mathrm{w}$ respectively. The more the TS level from 1.36 to $2.89 \% \mathrm{w} / \mathrm{w}$, the biogas yield increased from 58.66 to $130.44 \mathrm{~mL} / \mathrm{g}$ TS. However, further TS level $(3.49 \% \mathrm{w} / \mathrm{w})$ would decrease the biogas yield to become $78.38 \mathrm{~mL} / \mathrm{g}$ TS. Biogas yield had linear correlation with TS removal in which the more the TS was removed, the more the biogas yield was produced. The biogas evolution profile was a stepped curve for all substrates with RS addition. The profile was successfully predicted through double modified Gompertz models. Furthermore, based on Ratkowsky model, the optimum TS level to result the highest maximum biogas yield (239.63 $\mathrm{mL} / \mathrm{g}$ TS) was $3.14 \%$ w/w.

\section{Acknowledgements}

The authors special thank to the Diponegoro University through the World Class Research Program 2021 for supporting this research and the University of Sultan Ageng Tirtayasa for facilitating this research with an excellent laboratory.

\section{Conflict of Interest}

The authors declare no potential conflict of interest regarding the publication of this work. In addition, ethical issues including plagiarism, informed consent, misconduct, data fabrication and, or falsification, double publication and, or submission, and redundancy have been completely witnessed by the authors.

\section{References}

1. BUDIYONO, SUMARDIONO S., TRI MARDIANI D. Microwave Pretreatment of Fresh Water Hyacinth (Eichhornia crassipes) in Batch Anaerobic Digestion Tank. Int J Eng Transactions C: Aspects, 28 (6), 832, 2015.

2. KULKARNI M.B., GHANEGAONKAR P.M. Biogas generation from floral waste using different techniques. Global J. Environ. Sci. Manage. 5 (1), 17, 2019.

3. SYAICHURROZI I. Review - Biogas Technology to Treat Bioethanol Vinasse. Waste Tech, 4 (1), 16, 2016.

4. BUDIYONO, SYAICHURROZI I., SUMARDIONO S. Effect of Total Solid Content to Biogas Production Rate from Vinasse. Int J Eng Transactions B: Applications, 27 (2), 177, 2014.

5. SARTO S., HILDAYATI R., SYAICHURROZI I. Effect of chemical pretreatment using sulfuric acid on biogas production from water hyacinth and kinetics. Renew Energy, 132, 335, 2019.

6. KHAYUM N., ANBARASU S., MURUGAN S. Biogas potential from spent tea waste: A laboratory scale investigation of co-digestion with cow manure. Energy, 165, 760, 2018.

7. WANG H., XU J., SHENG L., LIU X. Effect of addition of biogas slurry for anaerobic fermentation of deer manure on biogas production. Energy, 165, 411, 2018.

8. ÖZER B. Biogas energy opportunity of Ardahan city of Turkey. Energy, 139, 1144, 2017.

9. BUDIYONO, SYAICHURROZI I., SUMARDIONO S. Biogas Production Kinetic from Vinasse Waste in Batch Mode Anaerobic Digestion. World Appl Sci J, 26, 1464, 2013.

10. BUDIYONO, WIDIASA I.N., JOHARI S., SUNARSO. The Influence of Total Solid Contents on Biogas Yield from Cattle Manure Using Rumen Fluid Inoculum. Energy Res J, 1 (1), 6, 2010.

11. YAVINI T.D., CHIA A.I., JOHN A. Evaluation of the Effect of Total Solids Concentration on Biogas Yields of Agricultural Wastes. Int Res J Environ Sci, 3 (2), 70, 2014. 
12. SHANKAR B.B., PATIL J.H., MURALIDHARA P.L., RAMYA M.C., RAMYA R. Effect of Substrate Concentration on Biomethanation of Water Hyacinth. Int J Chem Environ Biol Sci, 1 (1), 1, 2013.

13. JHA A.K., LI J., ZHANG L., BAN Q., JIN Y. Comparison between Wet and Dry Anaerobic Digestions of Cow Dung under Mesophilic and Thermophilic Conditions. Adv Water Resour Protect, 1 (2), 28, 2013.

14. IGONI A.H., ABOWEI M.F.N., AYOTAMUNO M.J., EZE C.L. Effect of Total Solids Concentration of Municipal Solid Waste on the Biogas produced in an Anaerobic Continuous Digester. Agric Eng Int, 10, 1, 2008.

15. KALIA V.C., SONAKYA V., RAIZADA N. Anaerobic digestion of banana stem waste. Bioresour Technol, 73, 191-193, 2000.

16. SINBUATHONG N., MUNAKATA-MARR J., SILLAPACHAROENKUL B., CHULALAKSANANUKUL $\mathrm{S}$. Effect of the solid content on biogas peoduction from Jatropha curcas seed cake. Proceedings of the Global Conference on Global Warning 2011, 1, 2011.

17. SYAICHURROZI I., RUSDI R., HIDAYAT T., BUSTOMI A. Kinetics Studies Impact of Initial $\mathrm{pH}$ and Addition of Yeast Saccharomyces cerevisiae on Biogas Production from Tofu Wastewater in Indonesia. Int J Eng Transactions B: Applications, 29 (8), 1037, 2016.

18. SYAICHURROZI I. Biogas production from co-digestion Salvinia molesta and rice straw and kinetics. Renew Energy, 115, 76, 2018.

19. SYAICHURROZI I., RUSDI, DWICAHYANTO S., TORON Y.S. Biogas Production from Co-Digestion Vinasse Waste and Tofu-Processing Wastewater and Kinetics. Int J Renew Energy Res, 6 (3), 1057, 2016.

20. SYAICHURROZI I., SUHIRMAN S., HIDAYAT T. Effect of initial $\mathrm{pH}$ on anaerobic co-digestion of Salvinia molesta and rice straw for biogas production and kinetics. Biocatal Agric Biotechnol 16, 594, 2018.

21. YUSUF M.O.L., DEBORA A., OGHENERUONA D.E. Ambient temperature kinetic assessment of biogas production from co-digestion of horse and cow dung. Res Agr Eng, 57 (3), 97, 2011.

22. YUSUF M.O.L., IFY N.L. The effect of waste paper on the kinetics of biogas yield from the co-digestion of cow dung and water hyacinth. Biomass Bioenerg, 35, 1345, 2011.

23. SYAICHURROZI I., BUDIYONO, SUMARDIONO S. Predicting kinetic model of biogas production and biodegradability organic materials: Biogas production from vinasse at variation of $\mathrm{COD} / \mathrm{N}$ ratio. Bioresour Technol, 149, 390, 2013.

24. FILER J., DING H.H., CHANG S. Biochemical Methane Potential (BMP) Assay Method for Anaerobic Digestion Research. Water 11, 921, 2019.

25. CRUZ-SALOMÓN A., MEZA-GORDILLO R., LAGUNAS-RIVERA S., VENTURA-CANSECO C. Biogas Production Potential from Native Beverage Vinasse of Mexico. Waste Technol, 5 (1), 9, 2017.

26. FERREIRA J.A., AGNIHOTRI S., TAHERZADEH M.J. Waste Biorefinery. Sustainable Resource Recovery and Zero Waste Approaches, 35, 2019.

27. PANICO A., D'ANTONIO G., ESPOSITO G., FRUNZO L., IODICE P., PIROZZI F. The Effect of SubstrateBulk Interaction on Hydrolysis Modeling in Anaerobic Digestion Process. Sustainability, 6, 8348-8363, 2014.

28. DARWIN, CHENG J.J., GONTUPIL J., LIU Z. Influence of total solid concentration for methane production of cocoa husk co-digested with digested swine manure. Int. J. Environ. Waste Manag, 17 (1), 71, 2016.

29. WARE A., POWER N. Modelling methane production kinetics of complex poultry slaughterhouse wastes using sigmoidal growth functions. Renew Energy, 104, 50, 2017.

30. KAFLE G.K., KIM S.H., SUNG K.I. Ensiling of fish industry waste for biogas production: a lab scale evaluation of biochemical methane potential (BMP) and kinetics, Bioresour Technol, 127, 326, 2012.

31. PATIL J.H., RAJ M.A., MURALIDHARA P., DESAI S., RAJU G.M. Kinetics of anaerobic digestion of water hyacinth using poultry litter as inoculum. Int J Environ Sci Dev, 3 (2), 94, 2012.

32. MAAMRI S., AMRANI M. Biogas production from waste activated sludge using cattle dung inoculums: Effect of total solid contents and kinetics study. Energy Procedia, 50, 352, 2014.

33. JÖNSSON L.J., MARTÍN C. Pretreatment of lignocellulose: formation of inhibitory by-products and strategies for minimizing their effects. Bioresour Technol, 199, 103, 2016.

34. PALMQVIST E., HAHN-HAGERDAL B.H. Fermentation of lignocellulosic hydrolysates.II: inhibitors and mechanisms of inhibition. Bioresour Technol, 74, 17, 2000.

35. TAHERZADEH M.J., KARIMI K. Acid-based hydrolysis processes for ethanol from lignocellulosic material: a review. J Bioresour, 2 (3), 472, 2007. 